\title{
Senate bill seeks to tighten controls on foreign researchers
}

Washington. An immigration reform bill introduced in the US Senate last week would, if passed in its current form, sharply reduce the number of foreign professional workers allowed into the country each year, and require non-US students to return home for at least two years after obtaining their degrees before being allowed to work in the United States.

The bill, sponsored by Senator Alan Simpson (Republican, Wyoming), would also force employers to pay substantially more to employ non-US than American workers, which its critics fear could discourage the hiring of foreign researchers.

The Simpson bill joins a bill already moving through the House of Representatives as the main vehicles for immigration reform in the current Congress (see Nature $376,373 ; \mathbf{1 9 9 5})$. Of the two, the Senate bill is more restrictive. Total employmentrelated immigration would drop from 140,000 a year to 90,000 a year - roughly the number admitted last year, not counting unskilled workers and Chinese students, who receive special consideration. The House bill would set the ceiling at 135,000 .

Under Simpson's bill, US employers would have to pay foreign-born workers at least as much as American workers. In addition, however, a further 25 per cent of the worker's salary would have to be paid by employers into a fund for training US workers. Temporary professional workers (those holding H-1B, H-2B and $L$ visas) would be allowed to stay for only three years, half of the period currently allowed. Their employers, too, would have to contribute up to 22.5 percent of the foreign employee's salary into a training fund.

Perhaps the most controversial clause for the university community will be the bill's stipulation that work visas will be granted only to those who have worked at least two years outside the United States after receiving their most recent degree effectively barring foreign students from staying on immediately after graduation. This requirement, says Simpson, "is intended to provide protection for US workers who are just beginning their careers".

Opinion polls consistently show that US voters favour tighter restrictions on immigration. But businesses and universities tend to be opposed, and have lobbied successfully to soften the harder edges of Smith's bill - including reinstating a special visa category for "outstanding researchers". The fate of Simpson's bill is therefore hard to predict, and will depend in part on how emotive the immigration issue becomes in next year's presidential election.

Tony Reichhardt

\section{Managed health-care adds to woes of US medical schools}

Washington. Medicare reform, the growth of managed health-care, and budget uncertainty at the National Institutes of Health (NIH) are combining into a powerful threat to both research and teaching at medical schools in the United States, academic leaders were told at a conference in Washington last week. "It is clear that funding from all sources is going to be severely constrained," said Jordan Cohen, president of the Association of American Medical Colleges (AAMC).

But Newt Gingrich (Republican, Georgia), the speaker of the House of Representatives, told the annual conference of the AAMC that the plight of the schools was appreciated in Congress. He announced his backing for plans for a 'trust fund' to replace the existing indirect flow of money from

Gingrich: backs fund Medicare - the sys- for teaching hospitals. tem that pays for

health-care for elderly Americans - into the teaching hospitals.

The fund, said Gingrich, would "put [the costs] on the table and educate the country about the importance of medical education, and why we as a government have a legitimate role in ensuring that it happens". But he added that the health-care system should not expect automatic increases in funding to allow for inflation.

Such indexing, he said, assumed no changes were being made to improve efficiency. "If you first set up a bureaucracy which is wasteful, fraudulent and incompetent, you then measure what that bureaucracy does, you then say that's the inflation rate because you can't get any smarter than the current bureaucracy," said Gingrich. "It becomes tautologically impossible."

Reform of Medicare and Medicaid - the smaller system that helps poor Americans of all ages - are part of the huge reconciliation budget bill that Congress will try to force President Bill Clinton to sign this month. Under the Republican plans, the government would buy health-care plans for many patients, instead of paying for their health-care directly. The money would therefore go to health maintenance organizations (HMOs) rather than hospitals, which use as much as $\$ 6$ billion of it each year to subsidize their medical schools

The Senate has now proposed a scheme that would take some of this money before it went to the HMOs, and redirect it to the hospitals. The House, in contrast, proposes a trust fund supported by a direct congressional appropriation for medical education, growing to $\$ 4$ billion a year by 2002 , to replace the existing indirect support. Biomedical lobbyists say both proposals would deprive the medical schools of more than $\$ 8$ billion in support between now and 2002 .

The two proposals arrive at a time when teaching hospitals are suffering severe revenue loss because of the national trend away from generous health insurance to "managed care' plans, which rigorously supervise how health-care money is spent.

Managed care is already dominant in some parts of the country, imposing shorter stays at cheaper institutions. According to George Mandel, chair of pharmacology at the George Washington University Medical Center in Washington DC, its impact has slashed the number of beds that the centre's hospital can support from 500 to 250 .

Sam Silverstein, chair of physiology at Columbia University in New York, and past president of the Federation of American Societies for Experimental Biology (FASEB), a biomedical lobby group, estimates that up to $\$ 1$ billion of general income each year supports research in the academic medical centres. But it does not show up in their accounts, Silverstein says, because the rules for indirect cost recovery discourage its declaration. Silverstein says that, in New York, the impact of the managed care revolution has still to be felt.

Apart from these indirect threats, biomedical researchers this month face the possibility of a severe squeeze on funding at $\mathrm{NIH}$, their main funding agency. Five weeks into the financial year, the NIH, like most of the rest of the government, has no budget agreed. Until 13 November, it will operate under a continuing resolution at 95 per cent of last year's funding level. After that, it may fall victim to a longer and even more severe continuing resolution. This week, NIH's political allies, led by George Gekas (Republican, Pennsylvania), will try to separate it from other elements in the federal budget, on the grounds that the House, the Senate and the administration all agree that it should get an increase in funding.

Most NIH grants start or resume at the beginning of December, and the NIH has written to all grant recipients warning them of the uncertainty. The nature of the extended continuing resolution will determine what they get in December. "We're looking at various different approaches," says Lee Pushkin, assistant director for budgets at NIH. Silverstein expects NIH to cut deeply into existing grants, if it must, to preserve the flow of new awards. Colin Macilwain 